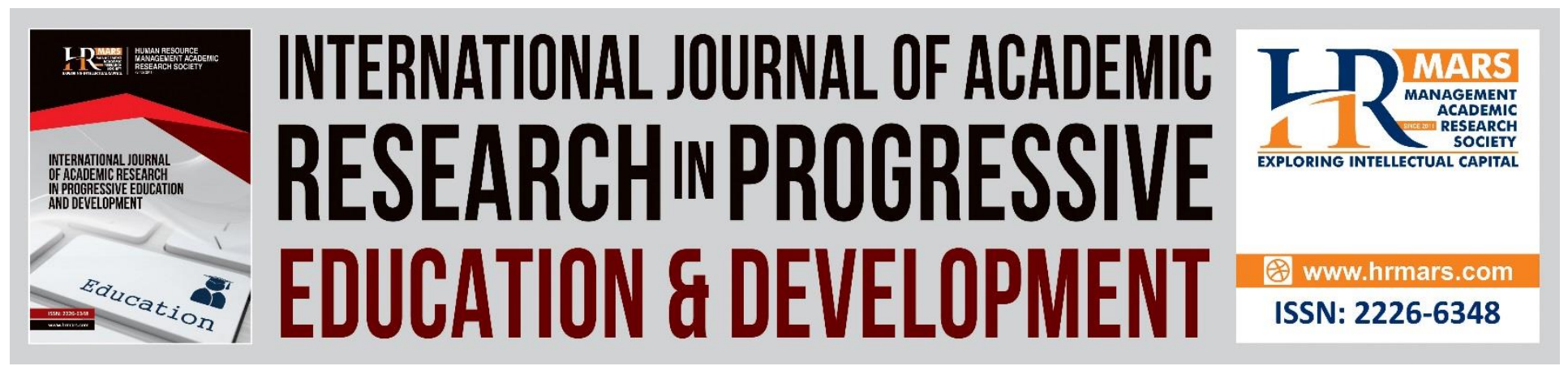

\title{
Implementation of Classroom Assessment Practices Among Teachers
}

Puteri Rothiah Binti Megat Yahaya, Mazarul Hasan Bin Mohamad Hanapi \& Faridah Hanim Binti Yahya

To Link this Article: http://dx.doi.org/10.6007/IJARPED/v9-i2/7499

DOI:10.6007/IJARPED/v9-i2/7499

Received: 14 April 2020, Revised: 20 May 2020, Accepted: 19 June 2020

Published Online: 29 July 2020

In-Text Citation: (Yahaya et al., 2020)

To Cite this Article: Yahaya, P. R. B. M., Hanapi, M. H. B. M., \& Yahya, F. H. B. (2020). Implementation of Classroom Assessment Practices Among Teachers. International Journal of Acdemic Research in Progressive Education and Development, 9(2), 527-533.

Copyright: (C) 2020 The Author(s)

Published by Human Resource Management Academic Research Society (www.hrmars.com)

This article is published under the Creative Commons Attribution (CC BY 4.0) license. Anyone may reproduce, distribute, translate and create derivative works of this article (for both commercial and non-commercial purposes), subject to full attribution to the original publication and authors. The full terms of this license may be seen

at: http://creativecommons.org/licences/by/4.0/legalcode

Vol. 9(2) 2020, Pg. 527 - 533

http://hrmars.com/index.php/pages/detail/IJARPED

JOURNAL HOMEPAGE

Full Terms \& Conditions of access and use can be found at http://hrmars.com/index.php/pages/detail/publication-ethics 


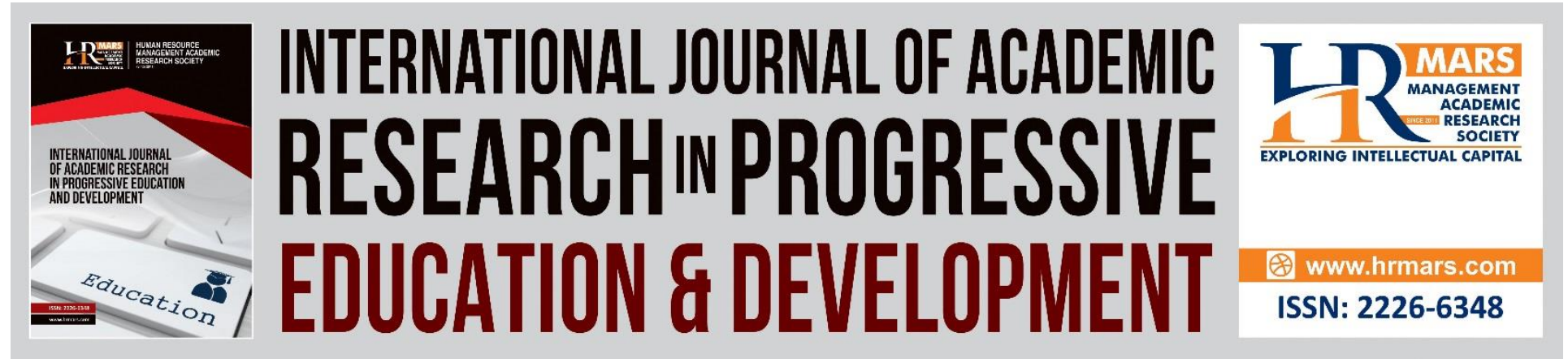

\title{
Implementation of Classroom Assessment Practices among Teachers
}

\author{
Puteri Rothiah Binti Megat Yahaya, Mazarul Hasan Bin Mohamad \\ Hanapi \& Faridah Hanim Binti Yahya \\ Faculty of Human Development, Universiti Pendidikan Sultan Idris, 35900, Tanjong Malim, \\ Perak, Malaysia
}

\begin{abstract}
The purpose of this research is to identify the assessment practice that need to be emphasized among teachers before making assessment. The result from the research found that show is five aspect need to be emphasized by the teachers before making assessment. Such as, alignment, belief in assessment, type of assessment, management assessment and management assessment creativity and innovation. Emphasized assessment practices before assessment is performed, will make sure that the assessment can be done by following the standard that have been set with the objectives that must be achieved and the content of the lesson to be assessed. Therefore, purpose of the assessment must be achieved as scheduled.
\end{abstract}

Keywords: Assessment, Creativity, Learning, Teaching, Teacher.

\section{Introduction}

Assessment aspect always be a popular topic because it can change day by day. For example, formerly Penilaian Tahun 6 change to Ujian Penilaian Sekolah Rendah (UPSR), Penilaian Menengah Rendah (PMR) change to Pentaksiran Tingkatan 3 (PT3) and so on. The way of assessment also be change on Pentaksiran Tingkatan 3(PT3) which is all the assessment will be reviewed by the teachers at their own school, which is before this assessment will be reviewed by the teachers from the other school. Same goes to High Level Thinking Skills (KBAT) are created in primary school and secondary school to encourage students to think more further and out of the box.

Assessment is one of the important elements to evaluate student's achievement. All the teachers have to take the initiative that leads to excellence of national education. With the objective good and perfect human being as well, which is have characteristics such as trust and obey to God, knowledgeable, have a good moral, have a responsible to yourself, society, religion, and country. Also be generous and to contribute to society and country also have a good manner is important too. 
Ali and Jamaluddin (2007); Darwish, Abdo, \& AlShuwaiee (2018) said teachers have lacks of skills in preparing and practicing Test Specification Table (JSU) is one of the cause teachers having difficulty in building assessment item. In Ali (2006) research, researcher found that most of the teachers more likely using the question from the examination questions guide years ago books without change or created their own questions. While researcher found idea that Alias (2003) gives, Test Specification Table (JSU) to make sure that all the question that have been created have a valid high content and must be from the content of the subject that they already learn from their teachers.

If the teachers creating test item based on Test Specification Table (JSU), assessment will be performed can be created by following the standard that have been set with the objective must be achieved and the lesson content to be assessed. Therefore, objective of the assessment will be achieved. All the teachers need to make the classroom assessment practices right to accepted the challenge. Education can develop student to be well prepared to go through global challenge.

\section{Literature Review}

Research from Ali and Jamaluddin (2007), there is a few teachers that lack of knowledge and skill in building assessment item. As effect, teachers cannot make their own examination questions (Malaysian Examination Institute, 2014). They also build examination questions without following the Test Specification Table (JSU) and standard in planning assessment item. This phenomenon causing the teachers to fail to monitor learning progress, and will not give a fair result, weak of learning planning and cannot know the real potential of the students.

From that scenario, its effect the report that will delivered to parents become not accurate (Jaafar \& Rahman, 2008). This situation will create distrust and doubt from various parties toward the quality of the assessment because of assessment accountability are failed to be fully performed (Talib \& Abd Ghafar, 2009).

According to Cheung, Leung, Zhang, Sun, Gan, Song and Xie (2001), most of the teachers felt that the changes of the education system have burdened them. Teachers felt that their schedule are very pack. Teachers are not only teaching but they also doing administration task and curriculum. Teachers need to teach and assess at the same time.

Research done by Ghavifekr, Kunjappan, Ramasamy and Anthony (2016), have found that teachers's attitude and perception are important to create effective innovation that have been performed. This is very important to measure how teachers see the innovation that have been used and the effectiveness to students as a device for learning and teaching.

Research from Abdul Khalil dan Awang (2016), were found that teachers are still lack of practices and basic skills also other reference sources to serve as a reference to performing the assessment. Therefore, they cannot perform the assessment in an accurate way especially in performing assessment based on Test Specification Table (JSU). Teachers need material source 
such as student learning development guide, sample instrumentation assessment manual and scoring assessment.

Research from Noraini et al (2013), in aspects of usage e-learning Eduweb TV in learning and teaching $(\mathrm{PdP})$ is at the low level. This situation can be happen because of teachers are lack of skill on integrate resource from Eduweb TV portal in learning and teaching (PdP) though teachers are given an ICT course in school education. Teachers are less creative in choosing, editing and rebuilding material from the Eduweb TV. These factors become obstacles to the teachers in applying Eduweb TV in learning and teaching (PdP).

Peng and Nadaraja (2016), they have found from the research is the level of thinking creatively skill of student is high. This situation shows teachers accept the challenge to produce students that have a rational and creative thinking. Students are given a chance to think and give an opinion. In this research, researcher also found that the execution of critical and creative thinking skills (KBKK) by the teachers are effective to the student. It shows that teachers always encourage student to participate in learning and teaching (PdP) that include with the critical and creative thinking skills (KBKK) activities.

All the past research also shows that teachers assessment practice are still less satisfying. Research by Ali (2006) found that the validity of the question content at the minimum level because of the teachers are depends on past questions.

Research by Muhammad (2006) found out that lecturers of Civil Engineering Department (JKA) in Politeknik Sultan Abdul Aziz Shah (SAAS) less comply to the real assessment practice which is assessment procedure, validity and test credibility. The attitude of the lecturers which is not trying more makes it hard to improve the student's potential to the next level.

From Rahman and Ali (2010), research found that teachers have a low attitude towards assessment activities because they think that assessment work have burden them. According to Desa (2009), most of the teachers have a less positive in assessment because everyone have their own personality. It is hard to make some work or too lazy to make some action due to abilities and intelligence.

Therefore, we need to handle this issues quickly and make world class education to be achieved. Be aware about the important of assessment practices, teachers need make some effort and high knowledge regarding to all things that need to do before handle the assessment. Such as alignment, belief in assessment, type of assessment, assessment management and also creativity and innovation are needed and to all the teachers to practice.

\section{Classroom Assessment Theory}

There is various theories in classroom assessment. This research is using integrated assessment model by Fautley \& Savage (2008). This model shows the relationship between learning and teaching (PdP). 


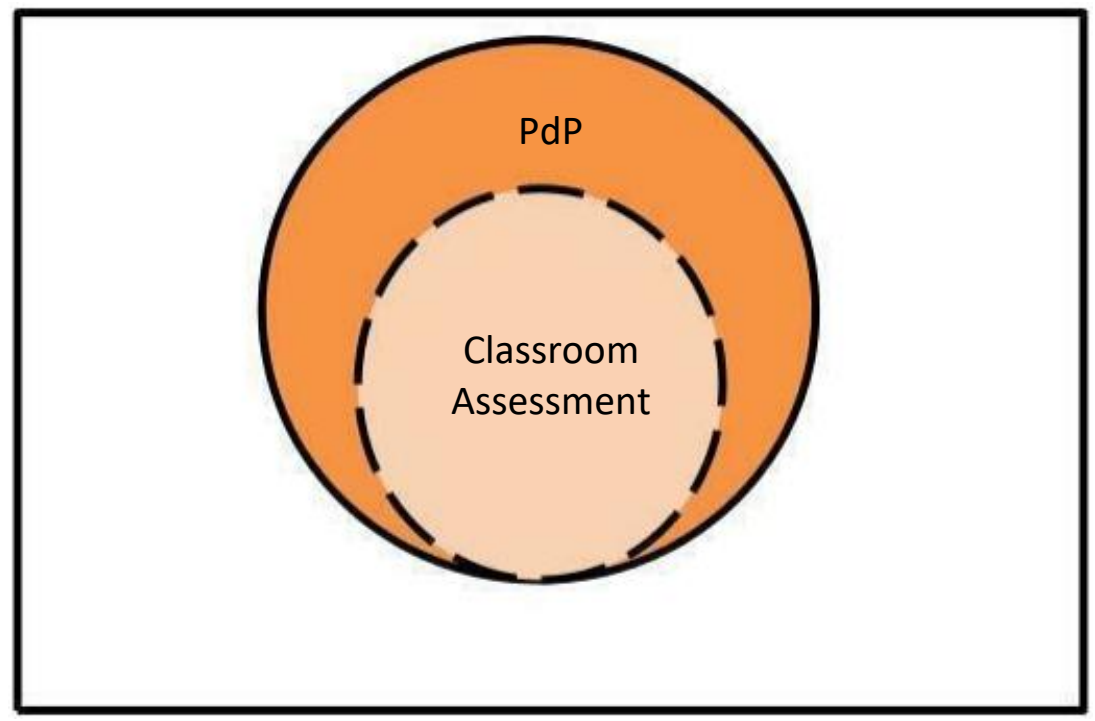

Diagram 1. Assessment in Learning and Teaching (PdP) adapted from Habibah (2016)

Learning and teaching (PdP) and assessment two different words but give a meaningful meaning in teaching and learning process. Actually assessment can be done before, during and after the learning and teaching process are performed. In Fautley and Savage (2008) opinion, learning and teaching process and assessment is the integrated elements as in Diagram 1 . The result of the learning and teaching enable teachers to modify the learning and teaching that leads towards students in understanding and achieve objective of learning that have been taught.

\section{Research Proposal}

Based on the past research, there is a few aspects should be emphasized by the teachers before making an assessment. Such as alignment, belief in assessment, type of assessment, assessment management and also creativity and innovation. Researcher have build conceptual framework from the past research and modify from ADDIE model (Gagne, Forest, Gilbert, Aube, Morin \& Malorni 2015) that shows five aspects that should be there before making an assessment. Diagram below shows conceptual framework as suggest by the researcher in this research. 
Vol. 9, No. 2, 2020, E-ISSN: 2226-6348 @ 2020 HRMARS

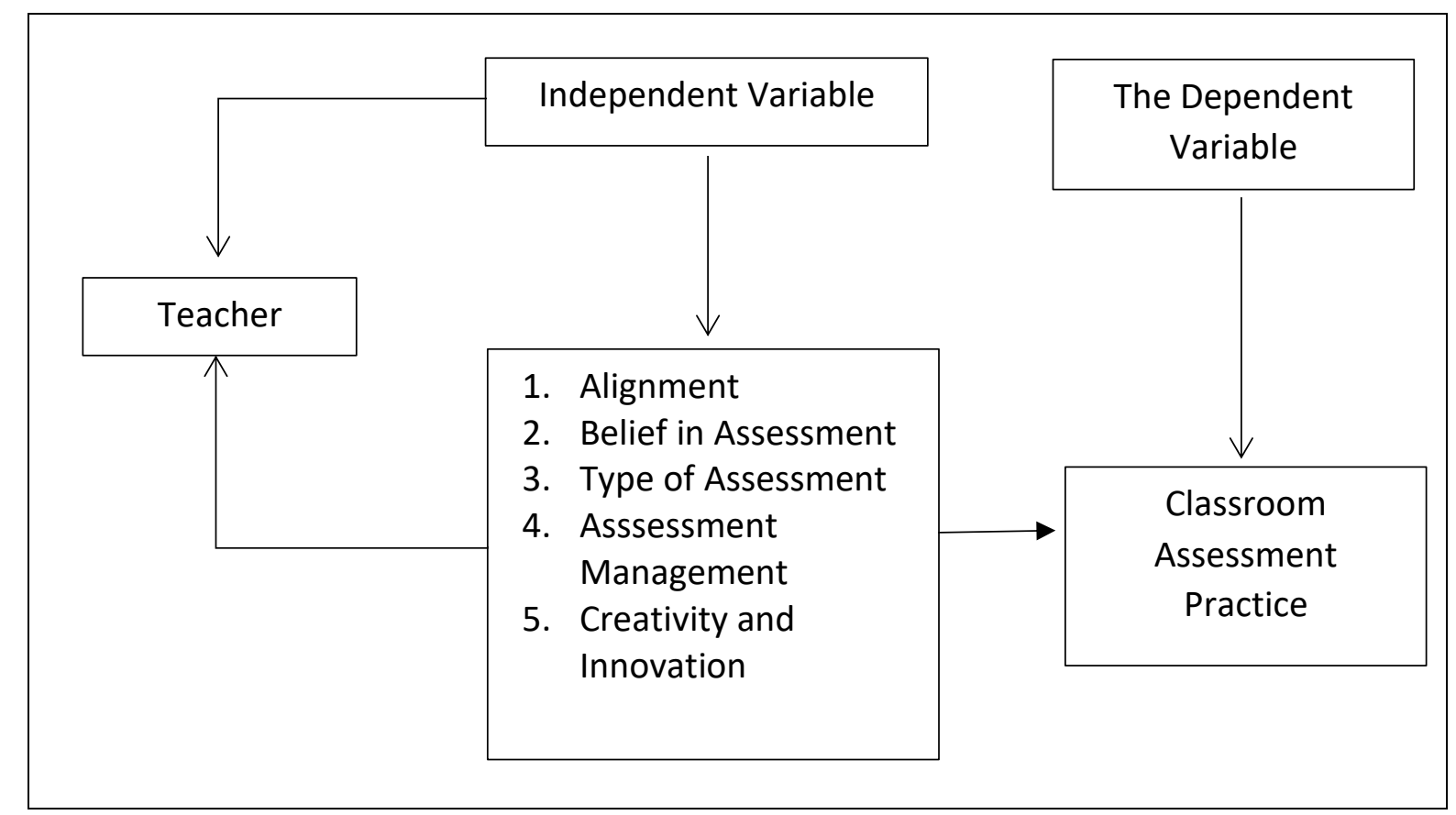

Diagram 2. Conceptual Framework (Modify from ADDIE model, Gagne et al., 2005)

\section{Acknowledgement}

Appreciation to all the parties involved in this research especially the headmaster and all the teachers who gave their full co-operation towards the research conducted.

\section{CORRESPONDING AUTHOR}

Puteri Rothiah Binti Megat Yahaya

Faculty of Human Development, Universiti Pendidikan Sultan Idris, Malaysia

Email: puterirothiahskrj@yahoo.com

\section{References}

Abdul Khalil, F., \& Awang, M. I. (2016). Isu kesediaan guru dalam amalan melaksanakan Pentaksiran Berasaskan Sekolah. EDUCATUM-Journal of Social Science, 2(1), 1-7.

Ali, M. A. M., \& Jamaluddin, S. (2007). Amalan pentaksiran untuk pembelajaran di sekolah menengah. Jurnal Pendidikan, 27(1), 19-39.

Ali, M. A. M. (2006). Amalan Pentaksiran Untuk Pembelajaran Di Sekolah Menengah. Institut Perguruan Tengku Ampuan Afzan Kuala Lipis Pahang.

Alias, M. (2003). Enhancing the Validity and Reliability of Classromm Test. Kertas Kerja Yang Dibentangkan Pada Seminar Pentaksiran Pendidikan Kebangsaa. Kuala Lumpur, 5 - 8 Mei 2003.

Cheung, F. M., Leung, K., Zhang, J. X., Sun, H. F., Gan, Y. Q., Song, W. Z., \& Xie, D. (2001). Indigenous Chinese personality constructs: Is the five-factor model complete? Journal of cross-cultural psychology, 32(4), 407-433. doi: 10.1177/0022022101032004003. 
INTERNATIONAL JOURNAL OF ACADEMIC RESEARCH IN PROGRESSIVE EDUCATION AND

DEVELOPMENT

Vol. 9, No. 2, 2020, E-ISSN: $2226-6348$ @ 2020 HRMARS

Darwish, S., Abdo, H., \& AlShuwaiee, W. M. (2018). Opportunities, challenges and risks of transition into renewable energy: the case of the Arab Gulf Cooperation Council. International Energy Journal, 18(4).

Desa, A. (2009). Psikologi Untuk Golongan Professional Edisi ke-3. Kuala Lumpur: McGraw Hill (Malaysia) Sdn Bhd.

Fautley, M., \& Savage, J. (2008). Assessment for Learning and Teaching in Secondary Schools. Learning Matters.

Gagne, J. R. (2005). Implementation of lonospheric Outflow in The LFM Global MHD Magnetospheric Simulatio. Doctoral dissertation, Dartmouth College.

Gagne, M., Forest, J., Gilbert, M. H., Aube, C., Morin, E., \& Malorni, A. (2015). The Motivation at Work Scale: Validation Evidence in Two Languages. Educational Psychological Measurement 70(4) 628-646.

Ghavifekr, S., Kunjappan, T., Ramasamy, L., \& Anthony, A. (2016). Teaching and Learning with ICT Tools: Issues and Challenges from Teachers' Perceptions. Malaysian Online Journal of Educational Technology, 4(2), 38-57.

Habibah, M. R. (2016). Amalan pentaksiran dalam pengajaran dan pembelajaran INSYA'sijil tinggi agama Malaysia (STAM)/Habibah Mat Rejab. Doctoral dissertation, University of Malaya.

Jaafar, K. B., \& Rahman, A. (2008). Pelaksanaan Pentaksiran kerja Kursus Kemahiran Hidup Bersepadu Sekolah Menengah Dalam Bandar Di Daerah Kuantan, Pahang. Universiti Teknologi Malaysia: Tesis Sarjana.

Ali, M. A. (2006). Amalan Pentaksiran Sekolah Menenggah di Malaysia. Universiti Malaya. Tesis PhD.

Muhammad, J. (2006). Amalan Pentaksiran Pencapaian Di Kalangan Pensyarah Jabatan Kejuruteraan Awam di Politeknik. Disertasi Sarjana Fakulti Pendidikan Teknikal, Kolej Universiti Teknologi Tun Hussien Onn, Johor.

Idris, N. (2010). Penyelidikan Dalam Pendidikan. Kuala Lumpur: McGraw Hill.

Rahman, M. A. B. A., \& Ali, Z. B. (2010). Pelaksanaan Pentaksiran Kerja Kursus Kemahiran Hidup Bersepadu Di Sekolah Menengah Luar Bandar Daerah Kuantan, Pahang. Universiti Teknologi Malaysia: Tesis Sarjana.

Peng, C. F., \& Nadaraja, S. (2016). Pelaksanaan kemahiran berfikir kreatif dan kritis dalam pengajaran dan pembelajaran komsas di sekolah menengah. Jurnal Pendidikan Bahasa Melayu, 4(2), 10-24.

Talib, R., \& Abd. Ghafar, M. N. (2009). Pembinaan dan Pengesahan Instrumen bagi Mengukur Tahap Literasi Pentaksiran Guru Sekolah Menengah di Malaysia. Universiti Teknologi Malaysia: Tesis PhD. 